\title{
Digitalization of MSMEs as the Key to Economic Recovery during the Pandemic
}

The COVID-19 pandemic has a major impact, especially on the economic sector in Indonesia. In accordance with the publication of the Central Bureau of Statistics, Indonesia's economy is experiencing deflation, especially in food, beverage, and tobacco groups. (Tayibnapis et al., 2021). Deflation itself indicates a decrease in demand for the group. In addition, the purchasing power of the community also decreased which due to social restrictions, making people dismissed from their jobs led to a lack of income.

One of the parties affected by the crisis from this pandemic is MSME businesses. This certainly needs to be taken seriously, especially judging by the data that states that MSMEs contribute quite a lot to GDP in Indonesia. From the information contained in the newspaper published by Jawa Pos sourced from the Ministry of SME, Indef, it is also mentioned that MSMEs contributed quite highly to the national economy in 2020, where MSMEs contributed $60 \%$ to GDP, $90 \%$ to the absorption of national labor and $14.37 \%$ to the total exports of MSMEs. Which means the weakening of small businesses and the crisis experienced can certainly threaten the economy.

One of the country's threats in this condition is the possibility of a recession, coupled with the fact that there is deflation and a decline in demand due to the low purchasing power of the people. The upper middle class, which doesn't actually have financial problems, is holding back their consumption due to safety factors. Most of them do not feel safe both healthily and financially, considering that no one knows for sure when this pandemic will end soon.

The government has taken various steps to restore the country's economy and increase the purchasing power of the community as well as efforts to maintain small and medium-sized micro enterprises. Deputy for Micro Enterprise of the Ministry of Cooperatives and SMEs stated that they will provide opportunities for Direct Cash Assistance of MSMEs and will accept old applicants and new applicants and it is expected that businesses can continue their business. He also said that they will try to keep maximizing the assistance intended for MSMEs. 
Beyond the many negative impacts affecting small businesses, this pandemic condition also increases new micro-businesses, where they are 'forced' to try more to be able to meet the needs of their consumption in these conditions. Even Bank Indonesia (BI) revealed that $12,5 \%$ of respondents were not affected by the Economy of the Covid-19 pandemic, and even 27,6\% percent of them showed an increase in sales.

Some small businesses are successfully surviving and increasing their sales under current conditions, on average because they have entered the realm of digitalization. Social restrictions make people refrain from making purchases offline, and switch to digital or online. Therefore, almost many businesses that only sell offline have decreased purchases. Until now, there are still quite a lot of small businesses that have not applied technology in their business. According to the Ministry of Cooperatives and MSMEs, the number of MSMEs utilizing digital technology is only 8 million or about $13 \%$ of the total MSMEs. (Tayibnapis et al., 2021). The importance of education about the use of digital technology for small businesses, especially for online payment technology. Although of course it is quite complex to integrate this evenly to all small businesses, efforts and strategies need to be made to boost the growth of MSMEs in Indonesia and increase competitiveness at the national and global level.

Every micro, small and medium entrepreneur needs to be able to personalize their digital tools and open up to the communities they need. (Tayibnapis et al., 2021)

Not only digitalization, but every MSMEs need to make the most of existing technology that is certainly in accordance with their work objectives. the application of such technology can be utilized by reaching out and connecting with each other to obtain information and make transactions. Moreover, the digitalization of payment and financing systems has the potential to open financial access for 62.9 million MSMEs and 51\% of the population (91.3 million people) who have not reached banking access.(Tayibnapis et al., 2021)

Digital transformation and innovation in MSMEs will not necessarily make the economy better, but it cannot be denied that technology plays an important role in the current situation. Limitations in social activities and security factors caused almost many of them still do not want to make 
purchases offline. It is evident from the data, that most only small businesses connected to digital platforms have experienced growth since the pandemic, where there has been a $26 \%$ increase in the number of online transactions. Meanwhile, small businesses that have not yet connected to digital platforms are experiencing a decrease in turnover.

MSMEs are an important asset and a driving factor for the national economy. So to restore the economy and ensure the wheels of the economy remain moving, it is necessary to improve the competitiveness of each MSMEs through collaboration. Inevitably businesses need to innovate through the digital ecosystem so so that they are not less competitive and can develop their products to the global market. Equitable digital transformation in MSMEs can further optimize efforts so as not only to increase marketing, but also to cut production costs.

It is necessary to empower small businesses to be able to compete in the international market. Product competitiveness must be continuously improved especially in terms of quality and price. Quality means related to materials, consistency of standards and also packaging. In addition, MSMEs are also required to be more efficient and varied so that their products are eligible to compete with the global market. Digitalization also certainly plays an important role for small businesses in order to be more accessible to the market and to increase business expansion. With digitalization, businesses can further optimize the production and efficiency of their business processes. This empowerment is expected to make MSMEs more ready, and able to compete competitively with products from the international market. 


\section{REFERENCES}

Tayibnapis, A. Z., Wuryaningsih, L. E., \& Gora, R. (2021). Medium, Small and Medium Enterprises and Digital Platforms. 10(2), 10-19.

https://doi.org/10.9734/SAJSSE/2021/v10i230258

Kompas.com. (2021). KemenkopUKM : Transformasi ke Digital Dorong UMKM Tetap Eksis Selama Pandemi. 4.

https://money.kompas.com/read/2021/04/26/202438626/kemenkopukm-transformasi-kedigital-dorong-umkm-tetap-eksis-selama-pandemi?page $=$ all.

KPCPEN. (2021). Menggenjot Sektor UMKM dan Daya Beli Publik di tengah Pandemi. 2021. https://covid19.go.id/berita/menggenjot-sektor-umkm-dan-daya-beli-publik-di-tengahpandemi

lipi.go.id. (2020). Membangkitkan UMKM di Masa Pandemi dengan Inovasi dan Teknologi. Lipi.Go.Id, 25391. http://lipi.go.id/siaranpress/membangkitkan-umkm-di-masa-pandemidengan-inovasi-dan-teknologi/22212

Medcom.id (2021). Kolaborasi dan Transformasi Digital, Strategi UMKM Hadapi Pandemi. 2376. https://www.medcom.id/ekonomi/entrepreneurship/Rb1mXQAb-kolaborasi-dantransformasi-digital-strategi-umkm-hadapi-pandemi.

Sulistyo. (2020). Pemberdayaan UMKM Menuju Go International. Investor.Id, 2021. https://investor.id/opinion/pemberdayaan-umkm-menuju-go-international 